\title{
FAKTOR-FAKTOR YANG MEMPENGARUHI KEPUASAN KONSUMEN APARTEMEN MEDITERANIA GARDEN RESIDENCE DI JAKARTA BARAT
}

\author{
Mimi SA ${ }^{1}$, Khairina Natsir ${ }^{2}$ \\ ${ }^{1}$ Fakultas Ekonomi, Universitas Tarumanagara Jakarta \\ Email: mimis@fe.untar.ac.id \\ ${ }^{2}$ Fakultas Ekonomi, Universitas Tarumanagara Jakarta \\ Email: khairinan@fe.untar.ac.id
}

\begin{abstract}
This study seeks to analyze the factors that influence consumer satisfaction. Independent variables are limited to service quality, facilities, location and price, while the dependent variable is consumer satisfaction. The research was conducted at Mediterania Garden Residence-1 Apartment, West Jakarta. Data collection was done by distributing questionnaires to 100 respondents who are residents of said apartment. Sampling technique used was probability sampling technique. By using multiple linear analysis technique and using SPSS software for data processing, the result of this study indicates that service quality, facilities, location and price positively and significantly impact consumer satisfaction. Service quality affects consumer satisfaction by 0.409 . The significance of the influence of Facility variable on consumer satisfaction is 0.223 , while the influence of location on consumer satisfaction is 0.175. Price variable contributes 0.248 to consumer satisfaction. Service quality becomes the most important factor affecting consumer satisfaction.
\end{abstract}

Keywords : Service Quality, Facility, Location, Price, Consumer Satisfaction.

\begin{abstract}
ABSTRAK
Penelitian ini bertujuan untuk menganalisis faktor-faktor yang mempengaruhi kepuasan konsumen. Variabel independen dibatasi pada kualitas pelayanan, fasilitas, lokasi dan harga, sementara variabel dependent adalah kepuasan konsumen. Penelitian dilakukan di Apartemen Mediterania Garden Residence1, Jakarta Barat. Metode pengumpulan data dilakukan dengan menyebarkan kuesioner kepada 100 responden yang merupakan penghuni dari apartemen tersebut. Teknik pengambilan sampel dengan probability sampling. Dengan menggunakan teknik analisis linier berganda dan penggunaan perangkat lunak SPSS untuk pengolahan data, hasil dari penelitian ini menunjukan bahwa kualitas pelayanan, fasilitas, lokasi dan harga berpengaruh positif dan signifikan terhadap variabel kepuasan konsumen. Kualitas pelayanan mempengaruhi kepuasan konsumen sebesar 0.409. Besarnya pengaruh variabel Fasilitas terhadap variabel kepuasan konsumen adalah sebesar 0.223, sementara pengaruh yang diberikan oleh variabel lokasi terhadap variabel kepuasan konsumen diperoleh sebesar 0.175. Variabel harga memberikan pengaruh sebesar 0.248 terhadap kepuasan konsumen. Kualitas pelayanan merupakan faktor yang paling berpengaruh terhadap kepuasan konsumen.
\end{abstract}

Kata kunci: kualitas pelayanan, fasilitas, lokasi,harga, kepuasan konsumen

\section{PENDAHULUAN Latar Belakang}

Ibu kota Jakarta memang memiliki daya tarik tersendiri bagi sebagian besar orang. Hal ini terbukti dengan semakin meningkatnya penduduk di Jakarta setiap tahunnya. Yang tentu saja berpengaruh pada sempitnya lahan hunian yang tersedia. Kondisi ini membuat para pengembang properti memilih membangun hunian tipe vertikal sebagai solusi sekaligus alternatif dari permasalahan tersebut. Geliat pertumbuhan apartemen di Jakarta Barat menunjukkan dominasinya saat ini. Hal ini tentu tidak terlepas dari banyaknya pusat bisnis, kampus-kampus, rumah sakit dan fasilitas umum lainnya yang berlokasi di Jakarta Barat. Berdasarkan hasil dari riset yang dilakukan Colliers, dilansir dari Kompas.com (Arimbi Ramadhiani, n.d.), menunjukan bahwa Jakarta Barat dan Jakarta Selatan masih menyandang sebagai kawasan yang paling diminati untuk proyek pengembangan apartemen strata-title dengan persentase sebesar $28 \%$ dari keseluruhan total pembangunan 
apartemen yang tengah berlangsung di Jakarta saat ini. Berdasarkan hasil tersebut, dapat dikatakan persaingan bisnis apartemen di Jakarta Barat sangatlah ketat. Pengelola harus mempunyai keunggulan dalam persaingan agar dapat memenangkan minat konsumen. Penelitian ini bertujuan untuk memberikan sumbangan pikiran kepada pengelola apartemen tentang faktor-faktor yang perlu diperhatikan oleh pengelola agar dapat memberikan kepuasan kepada konsumen apartemen, sehingga bisnis apartemen mereka mampu bersaing ditengah-tengah ketatnya bisnis penjualan hunian di Jakarta Barat. 4 (empat) variabel yang diduga berpengaruh terhadap konsumen apartemen diinvestigasi, yaitu faktor-faktor kualitas pelayanan, fasilitas, lokasi dan harga.

\section{Kajian Teoritis, Kerangka Pemikiran dan Perumusan Hipotesis}

Mengacu kepada pernyataan Philip Kotler dan Kevin Lane Keller yang dikutip dari buku Manajemen Pemasaran dikatakan bahwa kepuasan konsumen mengindikasikan perasaan senang atau kecewa seseorang yang timbul sewaktu membandingkan realisasi kinerja produk dengan kinerja yang diharapkan (Kotler \& Keller, 2007). Kepuasan juga merupakan respon konsumen terhadap tercukupinya kebutuhan. Kepuasan adalah suatu penilaian terhadap karakter atau keistimewaan produk atau jasa. Kepuasan merupakan tingkat kesenangan konsumen karena tercapainya kebutuhan konsumen. Namun, kepuasan adalah konsep yang jauh lebih luas daripada sekedar penilaian kualitas layanan, di mana rasa puas itu dipengaruhi oleh faktor-faktor yang lain seperti kualitas layanan, kualitas produk, harga, situasi yang sedang dialami oleh konsumen, dan karakter individu dari konsumen itu sendiri (Zeithalm \& Bitner, 2000)

Pihak apartemen tentunya melakukan pelayanan setiap saat, mereka memberikan pelayanan kepada penghuni apartemen setiap waktu. Pelayanan yang diberikan seperti penerima tamu, teknisi, staff keamanan, sampai penjaga gerbang parkir selalu tersedia 24 jam. Hal tersebut membuat kualitas pelayanan akan menjadi suatu yang sangat vital. Kualitas pelayanan menjadi salah satu ukuran atas keberhasilan dalam memberikan jaminan kepuasan bagi penghuni. Mengacu kepada definisi yang disampaikan oleh Kotler (2002) bahwa pelayanan merupakan suatu tindakan atau aktivitas yang direkomendasikan oleh suatu pihak kepada pihak lain, yang pada dasarnya tidak berbentuk dan tidak menimbulkan hak kepemilikan apapun. Menurut Supranto (2006) memberikan pengertian kualitas merupakan suatu istilah yang harus dikerjakan dengan sebaik-baiknya oleh penyedia jasa. Sementara itu Pandy Tjiptono (2006) dalam Maharani \& Dhiah (2010) berpendapat bahwa kualitas pelayanan merupakan suatu tingkat keutamaan yang diharapkan dan pengendalian atas tingkat keutamaan tersebut untuk memenuhi harapan konsumen. Dapat dipastikan kualitas pelayanan menjadi suatu hal yang penting dalam meningkatkan kepuasan konsumen. Menurut hasil penelitian yang dilakukan oleh Yoestini, Nugraheni, \& Kamal (2007) terhadap penghuni perumahan Puri Mediterania Semarang menyimpulkan bahwa kualitas pelayanan berpengaruh positif terhadap kepuasan konsumen.

Namun untuk memberikan kepuasan yang diharapkan penghuni, sudah menjadi standar bahwa apartemen memiliki berbagai fasilitas pendukung. Fasilitas pendukung yang ada misalnya, lahan parkir yang luas, kolam renang, lift barang dan penghuni, arena bermain anak, jogging track, klinik 24 jam, cctv yang aktif setiap saat dan sebagainya. Kotler (2005) memberikan definisi tentang fasilitas sebagai segala sesuatu yang berwujud dan dipersiapkan oleh pihak penjual jasa untuk tujuan mendukung kenyamanan konsumen. Berbagai penelitian tentang keterkaitan anatar fasilitas dan kepuasan dilakukan oleh para peneliti, diantaranya oleh (Afriadi \& Sitohang, 2016) pada penelitian yang dilakukan terhadap pasien rumah sakit bedah Surabaya menyimpulkan bahwa fasilitas berpengaruh positif terhadap kepuasan konsumen pasien sakit. 
Selain fasilitas, lokasi juga merupakan suatu komponen vital dalam produk apartemen. Kualitas produk apartemen ditentukan oleh lokasi bangunan itu sendiri. Menurut (Kotler, 2008), salah satu kunci kesuksesan adalah faktor lokasi. Lokasi diinisiasi dengan pemilihan lingkungan. Keputusan dalam pemilihan lokasi tentunya tergantung aspekaspek peluang pertumbuhan ekonomi, suhu persaingan, stabilitas, hawa politik, dan sebagainya. Beberapa aspek yang mesti diperhatikan dalam memilih lokasi menurut Kotler \& Keller $(2009,84)$ antara lain faktor akses atau kemudahan mendapatkan prasarana transportasi umum, visibilitas lokasi atau mudah terlihat jelas dari tepi jalan, ketersediaan sarana parkir yang luas dan aman, bersifat ekspansif atau tersedianya kawasan yang cukup memadai untuk pengembangan usaha di belakang hari, dan lingkungan yaitu kawasan sekitarnya yang menunjang kepada jasa yang ditawarkan. Penelitian tentang keterkaitan lokasi dan kepuasan konsumen diantaranya dilakukan oleh Ali \& Khuzaini (2017) yang melakukan riset pada keputusan pembelian Rumah Pada PT Bhummi Kartika Griya Persada dan menemukan bahwa Lokasi memiliki pengaruh yang signifikan dan positif terhadap Keputusan Pembelian Rumah Pada PT Bhummi Kartika Griya Persada

Faktor harga merupakan faktor penting dalam kepuasan konsumen. Harga menjadi suatu indikator, bahwa perusahaan menawarkan harga yang masuk akal untuk sebuah unit apartemen dengan segala komponen yang ada dapat melampaui harapan konsumen. Kotler \& Armstrong, $(2001,349)$ berpendapat bahwa harga adalah sejumlah uang yang ditukarkan terhadap suatu barang atau jasa dengan mempertimbangkan nilai atau manfaat atas penggunaan barang atau jasa tersebut. Sementara itu, Swastha \& Irawan (2005) memberikan definisi harga sebagai sesuatu yang dibutuhkan untuk memperoleh kombinasi pelayanan plus produk dengan menggantinya dengan sejumlah uang yang sudah ditentukan. Sedangkan Stanton (2008) berpendapat bahwa harga merupakan jumlah uang yang diperlukan untuk memperoleh sejumlah gabungan dari barang beserta pelayanannya. Riset yang dilakukan oleh peneliti Ahror \& Soekotjo (2017) menunjukkan pengaruh harga terhadap kepuasan pelanggan di cafe Milk Moo Sidoarjo adalah positif dan signifikan.

Berdasarkan teori yang sudah dijabarkan diatas memperlihatkan Kualitas pelayanan, Fasilitas, Lokasi dan Kesesuaian Harga, baik secara parsial ataupun secara bersama-sama akan memberikan pengaruh yang positif kepada konsumen.. Dalam penelitian ini peneliti ingin mengetahui bagaimana teori ini dapat berlaku pada pemasaran apartemen Mediterania-1 di Jakarta Barat. Kerangka pemikiran ini diperlihatkan dalam gambar berikut ini :

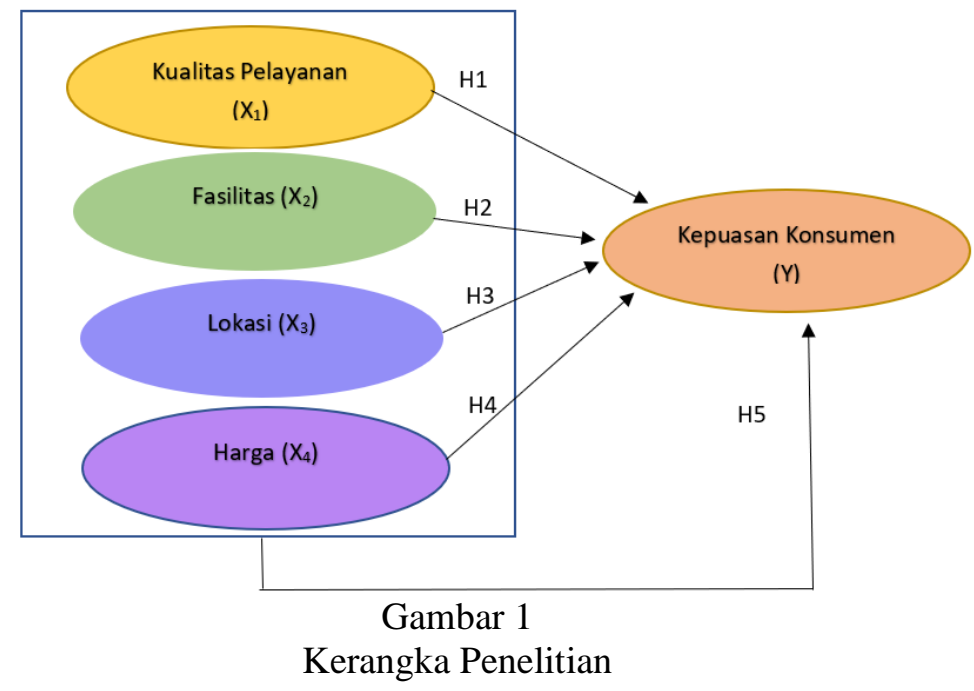


Sedangkan hipotesis penelitian yang merupakan dugaan sementara yang masih harus diuji lagi kebenarannya adalah sebagai berikut:

Hipotesis 1 : terdapat pengaruh yang signifikan kualitas pelayanan terhadap kepuasan penghuni Apartement Mediterania-1 Jakarta Barat

Hipotesis 2 : terdapat pengaruh yang signifikan fasilitas terhadap kepuasan penghuni Apartement Mediterania-1 Jakarta Barat

Hipotesis 3 : terdapat pengaruh yang signifikan lokasi terhadap kepuasan penghuni Apartement Mediterania-1 Jakarta Barat

Hipotesis 4 : terdapat pengaruh yang signifikan harga terhadap kepuasan penghuni Apartement Mediterania-1 Jakarta Barat

Hipotesis 5 : terdapat pengaruh secara bersama (simultan) antara kualitas pelayanan, fasilitas, lokasi dan harga terhadap kepuasan penghuni Apartement Mediterania-1 Jakarta Barat

\section{Rumusan Masalah}

Berdasarkan kepada kerangka pemikiran dan hipotesis yang sudah dijabarkan diatas, maka Perumusan masalah dalam penelitian ini disedifinisikan sebagai berikut:

a. Bagaimana pengaruh kualitas pelayanan terhadap kepuasan konsumen apartemen mediterania-1 di Jakarta Barat

b. Bagaimana pengaruh fasilitas terhadap kepuasan konsumen apartemen mediterania-1 di Jakarta Barat

c. Bagaimana pengaruh lokasi terhadap kepuasan konsumen apartemen mediterania-1 di Jakarta Barat

d. Bagaimana pengaruh harga terhadap kepuasan konsumen apartemen mediterania1 di Jakarta Barat

e. Bagaimana pengaruh variabel kualitas pelayanan, fasilitas, lokasi, dan variabel harga secara bersama-sama terhadap kepuasan konsumen apartemen mediterania1 di Jakarta Barat

\section{METODE PENELITIAN}

Dalam pelaksanaan penelitian ini digunakan 2 (dua) jenis variabel, yaitu variabel dependent (varibel terikat) dan variabel independen (variabel bebas). Variabel bebas dalam penenlitian ini adalah Kualitas Pelayanan $\left(\mathrm{X}_{1}\right)$, Fasilitas $\left(\mathrm{X}_{2}\right)$, Lokasi $\left(\mathrm{X}_{3}\right)$ dan Harga $\left(\mathrm{X}_{4}\right)$. Sedangkan sebagai variabel terikat adalah Kepuasan Konsumen (Y).

\section{Populasi dan Sampel dan Teknik Pengumpulan Data}

Populasi dari penelitian ini sebanyak 1640 orang penghuni apartement Mediterania Garden Residence di Jakarta barat. Pemilihan sampel yang digunakan adalah metode sampel secara acak sederhana berdasarkan frekuensi probabilitas semua anggota populasi. Dengan teknik pengambilan sampel acak, peluang setiap unsur atau anggota populasi untuk terpilih menjadi sampel adalah sama. Ukuran sampel dihitung dengan menggunakan rumus Slovin $n=\mathrm{N} /\left(1+\mathrm{N} e^{2}\right)$ dimana $\mathrm{N}$ adalah ukuran populasi, $\mathrm{n}$ adalah ukuran sampel minimal dan e adalah error tolerance. Hasil perhitungan menggunakan formula Slovin diperlukan sampel minimal sebanyak 94. Pada penelitian ini digunakan 100 sampel. Data penelitian merupakan data primer yang diukur dengan teknik survey dengan menyebarkan kuesioner menggunakan skala likert dari angka 1 sampai 5 (strongly disagree - strongly agree). 


\section{Analisis Data}

Analisis data dalam penelitian ini terdiri dari

1. Uji Data Alat Ukur, Pengujian alat ukur dilakukan dengan uji validitas dan uji reliabilitas.

2. Pengujian asumsi klasik, dilakukan dengan pengujian normalitas, multikolinieritas dan pengujian heteroskedastisitas

3. Analisis Regresi Multiple (Regresi Berganda), mengikuti bentuk persamaan berikut ini :

$\mathrm{Y}=\mathrm{a}+\mathrm{b}_{1} \mathrm{X}_{1}+\mathrm{b}_{2} \mathrm{X}_{2}+\ldots . .+\mathrm{b}_{\mathrm{n}} \mathrm{X}_{\mathrm{n}}$

4. Uji Hipotesis.

$>$ Uji t, merupakan pengujian signifikansi parameter individual dengan $\alpha=$ $5 \%$

$>$ Uji F, merupakan pengujian signifikansi parameter secara simultan dengan $\alpha=5 \%$

$>$ Uji Determinasi, merupakan pengujian untuk mengetahui kontribusi variabel independent terhadap variabel dependent.

\section{HASIL DAN PEMBAHASAN}

Hasil Uji Data Alat Ukur

Untuk menguji alat ukur pada penelitian ini digunakan uji validitas dan realibilitas kepada 100 responden. Suatu variable dikatakan valid apabila nilai $\mathbf{r}$ _hitung $>$ nilai $r \_t a b e l$. Pada penelitian ini dengan $n=100$ dan $\alpha=5 \%$, nilai $r$ tabel adalah 0.2. Berdasarkan hasil pengujian pada setiap variabel dengan bantuan olah data SPSS diperoleh $r$ hitung (corrected item-total correlation) $>0.2$, sehingga dapat dikatakan alat ukur valid dan dapat digunakan sebagai instrumen penelitian. Reliabilitas suatu variabel diidentifikasi dari koefisien Cronbach Alpha. Apabila koefisien Cronbach Alpha > 0.6, maka variable tersebut disebut reliabel (Ghozali, 2012). Hasil pengujian pada semua variabel penelitian ini menunjukkan nilai realibilitas Cronbach Alpha > 0.6. Oleh karena itu dapat dikatakan bahwa alat ukur sudah reliable dan layak digunakan pada penelitian ini.

\section{Hasil Analisis Data}

\section{Uji Asusmsi Klasik.}

Uji asumsi klasik merupakan syarat perlu secara statistik yang harus dipenuhi pada analisis regresi linear berganda yang berbasis ordinary least square.

a. Uji Normalitas. Uji bertujuan untuk menilai apakah dependent variable atau independent variable mempunyai sebaran secara normal. Uji normalitas pada penelitian ini menggunakan One-Sample Kolmogorov Smirnov Test. Hipotesis dalam uji normalitas adalah sebagai berikut:

$\mathrm{H}_{\mathrm{o}}$ : Data residual terdistribusi normal

$\mathrm{H}_{\mathrm{a}}$ : Data residual tidak terdistribusi normal

Dasar pengambilan keputusan adalah berdasarkan probabilitas. Jika nilai Sig > 0.05 maka Ho tidak ditolak, apabila nilai $\mathrm{Sig}<=0.05$ maka $\mathrm{H}_{\mathrm{o}}$ ditolak. Dari hasil uji normalitas dengan menggunakan teknik Kolmogorov - Smirnov diperoleh nilai Sig $=0.777$ yang berarti Ho tidak ditolak. Dengan demikian data residual telah terdistribusi normal

b. Uji Multikolinearitas. Uji ini dimaksudkan untuk menginvestigasi apakah ada hubungan linier diantara variabel independen. Untuk mendeteksi terdapat atau tidaknya multikolinieritas dalam model regresi, digunakan pendekatan nilai Variance Inflation Factor (VIF), dan nilai tolerance. Apabila nilai tolerance mendekati 1, serta nilai VIF berada pada interval 1-10, maka dapat dikatakan 
bahwa diantara variabel-variabel independen dalam model bebas dari multikolinieritas (Santoso, 2000). Output pengujian dengan bantuan software SPSS memperlihatkan bahwa diantara masing-masing variabel independen tidak terjadi korelasi karena nilai VIF kurang dari 10 dan nilai tolerance mendekati nilai 1. Dengan demikian variabel-variabel independen dalam penelitian ini bebas dari multikolinearitas.

c. Uji Heteroskedastisitas. Uji heteroskedastisitas bertujuan untuk menguji apakah dalam model regresi terjadi ketidaksamaan varian dari residual pada semua pengamatan regresi linier (Ghozali,2012). Uji Heteroskedastisitas dalam penelitian ini dilakukan menggunakan metode Glesjer, dimana pengujian dilakukan dengan cara meregresikan variabel independen terhadap nilai absolut residualnya. Jika nilai signifikansi (Sig) antara variabel independen dengan absolut residual $>0.05$ maka bebas dari masalah heteroskedastisitas. Dari hasil pengujian menggunakan SPSS pada variabel Kualitas Pelayanan, Fasilitas, Lokasi dan Harga diperoleh nilai Sig masing-masing sebesar 0.794, 0.156, 0.058 dan 0.106. Semua nilai Sig > 0.05 sehingga dapat disimpulkan tidak ada indikasi heterokedastisitas.

\section{Analisis Regresi Berganda.}

Analisis regresi pada dasarnya adalah suatu studi untuk mempelajari keterkaitan antara variabel-variabel independen dengan variabel dependen, dengan tujuan untuk mengestimasi atau memprediksi rata-rata populasi atau nilai- nilai variabel dependen berdasarkan nilai variabel independen yang diketahui (Ghozali, 2012).

Persamaan Regresi dalam penelitian ini adalah untuk mengetahui seberapa besar pengaruh variabel independen Kualitas Pelayanan, Fasilitas, Lokasi dan Harga terhadap Kepuasan Konsumen Penghuni Apartemen Mediterania-1. Hasil olah regresi berganda dapat dilihat pada tabel 1 berikut ini:

Tabel.1 Hasil Analisis Regresi Berganda

Coefficients $^{\mathrm{a}}$

\begin{tabular}{|c|c|c|c|c|c|c|c|}
\hline \multirow[t]{2}{*}{ Model } & \multicolumn{2}{|c|}{$\begin{array}{l}\text { Unstandardized } \\
\text { Coefficients }\end{array}$} & \multirow{2}{*}{$\begin{array}{l}\text { Standardized } \\
\text { Coefficients } \\
\text { Beta }\end{array}$} & \multirow[t]{2}{*}{$\mathrm{T}$} & \multirow[t]{2}{*}{ Sig. } & \multicolumn{2}{|c|}{ Collinearity Statistics } \\
\hline & B & Std. Error & & & & Tolerance & VIF \\
\hline (Constant) & .632 & 3.663 & & .172 & .863 & & \\
\hline Kualitas Pelayanan & .409 & .084 & .362 & 4.891 & .000 & .776 & 1.289 \\
\hline 1 Fasilitas & .223 & .077 & .222 & 2.903 & .005 & .724 & 1.381 \\
\hline Lokasi & .175 & .050 & .264 & 3.530 & .001 & .756 & 1.323 \\
\hline Harga & .248 & .097 & .210 & 2.552 & .012 & .628 & 1.593 \\
\hline
\end{tabular}

a. Dependent Variable: Kepuasan Konsumen

Persamaan analisis regresi ganda yang diperoleh dalam penelitian ini adalah:

Kepuasan_Konsumen $=0.632+0.409$ Kualitas_Pelayanan +0.223 Fasilitas + 0.175 Lokasi +0.248 Harga

\section{Pengujian Hipotesis}

Kecocokan fungsi regresi sampel dalam mengestimasi nilai aktualnya dapat dilihat dari Goodness of Fit-nya. Goodness of Fit dalam regresi diukur dari nilai koefisien determinasi, dan nilai statistik $t$, dan nilai statistik F. Jika nilai uji statistiknya berada dalam daerah kritis (daerah penolakan Ho), maka perhitungan statistik disebut signifikan. Sebaliknya, jika nilai uji statistiknya berada dalam daerah penerimaan $\mathrm{H}_{\mathrm{o}}$, maka perhitungan statistik tersebut dikatakan tidak signifikan ( Ghozali, 2012).

a. Uji Analisis Varians -Anova (Uji Statistik F). Uji bertujuan untuk menginvestigasi bagaimana pengaruh semua variabel independen secara 
serentak terhadap variabel dependen. Hasil uji F diperlihatkan pada tabel berikut

Tabel 2. - Hasil Uji F (Anova)

\begin{tabular}{|c|c|c|c|c|c|}
\hline Model & Sum of Soures & $\mathrm{Df}$ & Mean Sauare & $\mathrm{F}$ & $\mathrm{Si}_{\mathrm{S} \sigma}$ \\
\hline Regression & 614.180 & 4 & 153.545 & 35.206 & $.000^{\mathrm{b}}$ \\
\hline Residual & 414.330 & 95 & 4.361 & & \\
\hline Total & 1028.510 & 99 & & & \\
\hline
\end{tabular}

a. Dependent Variable: Kepuasan Konsumen

b. Predictors: (Constant), Harga, Kualitas Pelayanan, Lokasi, Fasilitas

Berdasarkan hasil pengujian pada Tabel 2, $\mathrm{H}_{\mathrm{o}}$ ditolak dan $\mathrm{H}_{\mathrm{a}}$ diterima karena nilai signifikansi pada tabel menunjukan hasil yang lebih kecil dari 0.05. Hal ini berarti adanya pengaruh yang berarti (signifikan) antara variabel-variabel kualitas pelayanan, fasilitas, lokasi dan harga terhadap variabel kepuasan konsumen dengan tingkat keyakinan $95 \%$.

b. Uji Signifikansi Variabel secara Parsial (uji t).

Uji t pada prinsipnya bertujuan untuk mengestimasi seberapa besar pengaruh satu variabel independen secara parsial (individual) dalam menjelaskan variasi variabel dependen (Ghozali, 2012).

Uji $\mathrm{t}$ dilakukan untuk menginvestigasi kebenaran hubungan antara variabel independen dan Variabel dependen secara parsial, apakah variabel Kualitas Pelayanan, Fasilitas, Lokasi dan Harga benar-benar memberi pengaruhi kepada variabel Kepuasan Konsumen secara terpisah.

Hasil uji t diperlihatkan pada tabel berikut ini.

Tabel 3. Hasil Uji t

\begin{tabular}{|c|c|c|c|c|c|c|c|c|}
\hline \multirow{2}{*}{\multicolumn{2}{|c|}{ Model }} & \multicolumn{2}{|c|}{$\begin{array}{l}\text { Unstandardized } \\
\text { Coefficients }\end{array}$} & \multirow{2}{*}{$\begin{array}{l}\text { Standardized } \\
\text { Coefficients } \\
\text { Beta } \\
\end{array}$} & \multirow[t]{2}{*}{$\mathrm{T}$} & \multirow[t]{2}{*}{ Sig. } & \multicolumn{2}{|c|}{$\begin{array}{l}\text { Collinearity } \\
\text { Statistics }\end{array}$} \\
\hline & & $\mathrm{B}$ & Std. Error & & & & Tolerance & VIF \\
\hline \multirow{5}{*}{1} & (Constant) & .632 & 3.663 & & .172 & .863 & & \\
\hline & Kualitas Pelayanan & .409 & .084 & .362 & 4.891 & .000 & .776 & 1.289 \\
\hline & Fasilitas & .223 & .077 & .222 & 2.903 & .005 & .724 & 1.381 \\
\hline & Lokasi & .175 & .050 & .264 & 3.530 & .001 & .756 & 1.323 \\
\hline & Harga & .248 & .097 & .210 & 2.552 & .012 & .628 & 1.593 \\
\hline
\end{tabular}

a. Dependent Variable: Kepuasan Konsumen

Berdasarkan hasil uji $\mathrm{t}$ seperti tertera pada Tabel 3 diatas, maka hasil uji hipotesis dapat dijelaskan sebagai berikut :

- Hasil uji hipotesis pertama diperoleh nilai signifikansi $=0.000$, atau sig $<$ 0.05 , dengan demikian hipotesis pertama diterima.

- Hasil uji hipotesis kedua diperoleh nilai signifikansi $=0.005$, atau sig < 0.05 , dengan demikian hipotesis diterima.

- Hasil uji hipotesis ketiga diperoleh nilai signifikansi $=.001$, atau sig < 0.05, dengan demikian hipotesis ketiga diterima.

- Hasil uji hipotesis keempat diperoleh nilai signifikansi $=0.012$, atau sig < 0.05. sehingga hipotesis keempat diterima.

c. Analisis Koefisien Determinasi $\left(\mathrm{R}^{2}\right)$.

Uji $\mathrm{R}^{2}$ dapat dipakai untuk mengukur seberapa besar kontribusi variabelvariabel independen dalam model untuk menjelaskan variabel dependen (Ghozali, 2012).

Nilai $\mathrm{R}^{2}$ berkisar antara nol dan satu. Nilai $\mathrm{R}^{2}$ yang kecil menunjukkan kontribusi variabel-variabel independen dalam menjelaskan variasi variabel dependen sangat terbatas. Nilai $\mathrm{R}^{2}$ yang mendekati satu berarti variabel-variabel 
independen mampu menjelaskan hampir semua informasi yang dibutuhkan untuk memprediksi variasi variabel dependen (Ghozali, 2012)

Hasil pengujian untuk koefisien determinasi pada penelitian ini ditampilkan pada tabel berikut:

Tabel 4. Hasil Uji Koefisien Determinasi

\begin{tabular}{lcccc}
\multicolumn{4}{l}{ Model Summary } \\
\hline Model & $\mathrm{R}^{2}$ & R Square & Adjusted R Square & $\begin{array}{l}\text { Std. Error of the } \\
\text { Estimate }\end{array}$ \\
\hline 1 & $.773^{\mathrm{a}}$ & .597 & .580 & 2.08839 \\
\hline a. Predictors: (Constant), Harga, Kualitas Pelayanan, Lokasi, Fasilitas \\
b. Dependent Variable: Kepuasan Konsumen
\end{tabular}

Berdasarkan Tabel 4. dapat diketahui bahwa nilai $\mathrm{R}^{2}$ yang diperoleh sebesar $59,7 \%$. Ini memperlihatkan bahwa variabel-variabel kualitas pelayanan, fasilitas, lokasi dan harga berkontribusi sebesar $59.7 \%$ dalam menjelaskan variabel kepuasan konsumen penghuni apartemen mediterania1, sementara $40.3 \%$ dijelaskan oleh variabel lain yang tidak terlibat dalam penelitian ini.

\section{Pembahasan}

Berdasarkan hasil analisis data diatas, maka hasil pengujian terhadap 5 (lima) hipotesis penelitian adalah sebagai berikut:

- Hipotesis pertama diterima, yaitu kualitas pelayanan berpengaruh positif secara individu terhadap kepuasan konsumen, sehingga dapat disimpulkan bahwa semakin baik kualitas pelayanan akan semakin meningkatkan kepuasan konsumen penghuni apartemen Mediterania1. Kesimpulan ini diperoleh dari hasil analisis yang menunjukkan nilai signifikansi sebesar $0.00<0.05$ Hasil ini menunjukkan bahwa pelayanan yang diberikan seperti penerima tamu, teknisi, staff keamanan, sampai penjaga gerbang parkir selalu tersedia 24 jam dirasa cukup baik dan secara maksimal dapat memuaskan dimata konsumen. Oleh karena itu pengelola apartemen harus terus menerus berupaya meningkatkan kualitas pelayanannya gara kepuasan konsumen tidak menurun.

- Hipotesis kedua diterima yaitu fasilitas berpengaruh positif secara partial terhadap kepuasan konsumen, sehingga semakin tinggi (baik) fasilitas yang diberikan oleh pengelola apartemen mediterania-1 akan meningkatkan kepuasan konsumen penghuni apartemen tersebut. Kesimpulan ini didapatkan karena hasil analisis yang menunjukkan nilai signifikansi $0.005<0.05$. Oleh karena itu untuk menaja kepuasan konsumen penghuni apartemen, maka ketersediaan fasilitas umum yang semakin baik harus selalu difikirkan oleh pengelola apartemen, seperti pemeliharaan lift secara teratur, ketersediaan kolam renang, mesin ATM dan segala sesuatu yang diperlukan untuk menunjang aktivitas sehari-hari.

- Hipotesis ketiga diterima, yaitu lokasi berpengaruh positif secara partial terhadap kepuasan konsumen, ini artinya semakin baik lokasi apartemen akan semakin meningkat kepuasan konsumen apartemen. Kesimpulan ini diperoleh karena hasil analisis yang menunjukkan nilai signifikansi sebesar $0.01<0,05$. Hal ini menunjukkan bahwa konsumen akan semakin merasa puas jika keterjangkauan lokasi apartemen dengan tempat-tempat penting selalu menjadi perhatian pengelola partmen. Oleh karena itu pengelola apartemen harus selalu berupaya untuk menyediakan kemudahan dalam bertransportasi seperti penyediaan lahan parkir yang memadai, pengembangan lingkungan yang kondusif, penyediaan transportasi khusus ke tempat-tempat penting. 
- hipotesis yang keempat diterima, yaitu harga berpengaruh positif secara partial terhadap kepuasan konsumen, Kesimpulan ini didapatkan karena hasil analisis yang menunjukkan nilai signifikan variabel harga sebesar $0.012<0.05$. Hal ini menunjukkan bahwa konsumen merasakan bahwa harga yang mereka bayarkan sebanding dengan produk yang mereka impikan. Artinya keberadaan apartem dengan segala kualitas yang ada mampu membuat konsumen merasa puas. Hal ini menjadi suatu tantangan bagi pengelola apartemen agar tidak menurunkan kualitas sbuah apartemennya karena konsumen merasa bahwa harga yang mereka bayarkan adalah untuk sebuah kualitas.

- hipotesis kelima diterima yaitu kualitas pelayanan, fasilitas, lokasi dan harga secara bersama-sama berpengaruh positif terhadap kepuasan konsumen. Hal ini terlihat dari hasil uji F dimana nilai signifikansinya sebesar $0.000<0,05$

Jika ditinjau dari besarnya pengaruh yang diberikan oleh setiap variabel independen terhadap variabel dependen, hasil penelitian ini menunjukkan bahwa kualitas pelayanan memberikan pengaruh terhadap kepuasan konsumen sebesar 0.409. Variabel fasilitas memberikan pengaruh sebesar 0.223 terhadap kepuasan konsumen. Sementara itu pengaruh variabel lokasi memberikan pengaruh sebesar 0.175 terhadap kepuasan konsumen. Pengaruh dari variabel harga terhadap kepuasan konsumen adalah sebesar 0.248. Kualitas pelayanan merupakan faktor yang paling besar memberikan pengaruh terhadap kepuasan konsumen. Oleh karena itu pengelola harus selalu berusaha meningkatkan semua faktor-faktor diatas agar kepuasan konsumen selalu meningkat, terutama yang berkaitan dengan kualitas pelayanan, seperti fasilitas fisik, berusaha selalu mewujudkan janji dan kualitas jasa, responsif terhadap konsumen, adanya jaminan dalam pelayanan serta adanya rasa empati terhadap konsumen.

Hasil dari penelitian ini maka dapat dilihat bahwa penelitian ini memperkuat temuan yang sudah dilakukan oleh para peneliti sebelumnya. Adanya pengaruh positif variabel harga terhadap kepuasan konsumen sejalan dengan penelitian yang dilakukan oleh Ahror \& Soekotjo (2017). Sementara itu adanya pengaruh positif dan signifikan variabel kualitas pelayanan terhadap kepuasan konsumen sejalan dengan hasil penelitian yang dilakukan oleh Yoestini, Nugraheni, \& Kamal (2007). Adanya pengaruh variabel Fasilitas terhadap kepuasan konsumen konsisten pula dengan penelitian terdahulu yang dilakukan oleh Afriadi \& Sitohang (2016). Kemudian hasil penelitian ini yang menyatakan adanya pengaruh positif dan signifikan variabel Lokasi terhadap kepuasan konsumen sejalan pula dengan penelitian yang dilakukan oleh Ali \& Khuzaini (2017).

\section{KESIMPULAN DAN SARAN}

Dari hasil penelitian ini dapat disimpulkan bahwa variable kualitas pelayanan, fasilitas, lokasi dan harga berpengaruh positif baik secara parsial ataupun secara bersama-sama terhadap kepuasan konsumen pada apartemen Mediterania-1 di Jakarta Barat.

Oleh karena itu kiranya pengelola apartemen Mediterania-1 dapat meningkatkan kepuasan konsumen dengan cara lebih meningkatkan lagi kualitas pelayanan, dan fasilitas yag dimiliki agar mampu mendorong kepuasan konsumen yang pada akhirnya akan dapat membantu meningkatkan jumlah konsumen. Selain itu, manajemen hendaknya juga memperhatikan indikator dari variabel harga yang meliputi kesesuaian harga produk dengan manfaat yang diperoleh sehingga konsumen merasa puas atas nilai yang sudah mereka bayarkan. Kepuasan konsumen juga harus selalu ditingkatkan dengan ketersediaan sarana-sarana parkir, olahraga dan sarana kebutuhan lainnya yang nyaman.

\section{REFERENSI}

Afriadi, Y., \& Sitohang, S. (2016). Pengaruh Kualitas Layanan, Harga, Dan Fasilitas Terhadap Kepuasan Pasien Rawat Inap. Jurnal Ilmu Dan Riset Manajemen, 5(June 
2016).

Ahror, U. Al, \& Soekotjo, H. (2017). Pengaruh Kualitas Pelayanan, Harga Dan Lokasi Terhadap Kepuasan Pelanggan Cafe Milkmoo. Jurnal Ilmu Dan Riset Manajemen, 6(3).

Ali, M. T. R., \& Khuzaini. (2017). Pengaruh Harga, Kualitas Produk, Lokasi, Dan Fasilitas Terhadap Keputusan Pembelian Rumah. Jurnal Ilmu Dan Riset Manajemen, 6(September 2017).

Arimbi Ramadhiani. (N.D.). Jakarta Barat Dan Selatan Masih Jadi Favorit Pengembang Apartemen Artikel Ini Telah Tayang Di Kompas.Com Dengan Judul "Jakarta Barat Dan Selatan Masih Jadi Favorit Pengembang Apartemen”, Https:/Properti.Kompas.Com/Read/2016/11/03/162302421/Jakarta.Barat.

Ghozali, I. (2012). Aplikasi Analisis Multivariate Ibm Spss 23. Semarang: Badan Penerbit - Universitas Diponegoro.

Kotler, P. (2002). Manajemen Pemasaran (10th Ed.). Jakarta: Prenhallindo.

Kotler, P. (2005). Manajemen Pemasaran, Jilid I Dan Ii. Jakarta: Pt. Indeks.

Kotler, P. (2008). Manajemen Pemasaran. Edisi Milenium. Jakarta: Pt. Prenhallinda.

Kotler, P., \& Armstrong, G. (2001). Prinsip-Prinsip Pemasaran, Jilid 1 Dan 2 (8th Ed.). Jakarta: Erlangga.

Kotler, P., \& Keller, L. (2009). Manajemen Pemasaran. (13th Ed.). Jakarta: Erlangga.

Kotler, \& Keller. (2007). Manajemen Pemasaran (12th Ed.). Jakarta: Pt.Indeks.

Maharani, \& Dhiah, A. (2010). Analisis Pengaruh Kepercayaan Dan Kepuasan Terhadap Loyalitas Nasabah Tabungan Bank Mega Syariah Cabang Semarang, Semarang, (Universitas Diponegoro Semarang).

Santoso, S. (2000). Spss Statistik Parametrik (1st Ed.). Jakarta: Pt Elexmedia Komputindo.

Stanton, W. J. (2008). Fundamental Of Marketting. Mc Graw Hill, Inc.

Supranto, J. (2006). Pengukuran Tingkat Kepuasan Konsumen Untuk Menaikkan Pangsa Pasar. Jakarta: Pt. Asdi Mahasatya.

Swastha, B., \& Irawan. (2005). Manajemen Pemasaran Modern. Yogyakarta: Liberty.

Tjiptono, F. (2006). Manajemen Jasa. Edisi Keempat. Yogyakarta: Andi.

Yoestini, B. H. M., Nugraheni, R., \& Kamal, M. (2007). Analisis Pengaruh Kualitas Produk Dan Kualitas Layanan Terhadap Kepuasan Konsumen (Studi Kasus Pada Perumahan Puri Mediterania Semarang). Jurnal Studi Manajemen \& Organisasi, $I V(2), 91$. Retrieved from http://ejournal.undip.ac.id/index.php/smo 